\title{
Jak pogłębiać więzi młodych ludzi z ich miejscem zamieszkania? Wędrówki po Krakowie inspirowane twórczością Doroty Terakowskiej
}

\author{
How to deepen the bonds of young people with their \\ place of residence? Wandering around Krakow inspired \\ by the work of Dorota Terakowska
}

\author{
\# $\begin{aligned} & \text { Katarzyna Maria Pławecka } \\ & \text { Uniwersytet Pedagogiczny w Krakowie }\end{aligned}$
}

\begin{abstract}
The article entitled: How to deepen the bonds of young people with their place of residence? Wandering around Krakow inspired by the work of Dorota Terakowska fits in the broad issues of didactics of literature and language in the contemporary school. A special reflection is put on fostering young people's love for reading texts about their nearest region (the place of their residence). A proposal for a literary tour around Krakow is included in the framework of a specially designed project, thanks to which it is possible to take elementary school students to two different (and therefore not boring) worlds: 1) real places close to their life experience; 2) parallel places, recorded in the literature of Dorota Terakowska, i.e., Babci Brygidy szalona podróż po Krakowie, Władca Lewawu. The proposed activities, as it turned out in practice, were an effective way of encouraging students to read and "grow roots into the soul".
\end{abstract}

Key words: a small homeland; regional education; experiencing a place; shaping the identity of youth; Dorota Terakowska's creativity; teaching Polish

Streszczenie: Artykuł Jak pogłębiać więzi młodych ludzi z ich miejscem zamieszkania? Wędrówki po Krakowie inspirowane twórczościq Doroty Terakowskiej wpisuje się w szeroką problematykę dydaktyki literatury i języka w szkole współczesnej. Szczególny namysł dotyczy rozbudzania w młodych ludziach miłości do czytania lektur i najbliższego regionu (miejsca zamieszkania). W ramy specjalnie opracowanego projektu włącza się propozycję wycieczki literackiej po Krakowie, dzięki której możliwa jest podróż uczniów szkoły podstawowej do dwóch odmiennych (a przez to nienudnych) światów: 1) miejsc realnych, bliskich ich doświadczeniu życiowemu; 2) miejsc równoległych, utrwalonych w literaturze Doroty Terakowskiej tj.: Babci Brygidy szalona podróż po Krakowie, Władca Lewawu. Proponowane działania, jak się okazało w praktyce, stanowiły skuteczną formę zachęcania uczniów do czytania oraz „puszczania korzeni w duszę”.

Słowa kluczowe: mała ojczyzna; edukacja regionalna; doświadczanie miejsca; kształtowanie tożsamości młodzieży; twórczość Doroty Terakowskiej; nauczanie języka polskiego 


\section{Więzi dziecka z najbliższym środowiskiem - perspektywa historyczna}

Celem artykułu jest zwrócenie uwagi na specyfikę miejsca traktowanego jako szeroko rozumiana wartość w życiu człowieka. Prezentowana tematyka łączy się z edukacją polonistyczną i wywołuje z pamięci założenia nieobecnego (niestety!) we współczesnej szkole dokumentu ministerialnego Dziedzictwo kulturowe w regionie. Założenia programowe MEN (Warszawa 1999). Podkreślano wówczas znaczenie świadomości poczucia więzi z „małą ojczyzną” jako ważnego czynnika mającego wpływ na formowanie osobowości młodego człowieka, jego tożsamości. Interesujące postulaty programowe wyprowadzano z edukacji międzywojnia, kiedy to szczególnie doceniano wielorakie znaczenie wychowawczo-dydaktyczne kultury regionu w nauczaniu szkolnym. Związek człowieka z konkretnym miejscem łączono z tzw. siłą więzi „z przyrodzenia”. Inspirowano się ponadczasowymi przemyśleniami Grzegorza Piramowicza, które nic nie straciły ze swojej aktualności. O miłości i wychowaniu pisał on niezwykle pięknie:

Z tego źródła miłości ku rodzicom, przywiązania do rodzeństwa i krewnych wypływa jeszcze powinność kochania ojczyzny swojej. Mają to ludzie powszechnie z wychowania i prawie z przyrodzenia, iż miejsce, w którym życie odebrali, w którym wypielęgnowali ich rodzice, w którym posiadają majątek, to mówię miejsce bardzo lubią, przenosząc je nad inne miejsca, życzą współziomkom swoim więcej niż innym, radzi by widzieli, żeby ich miasto wieś, kraina opływała we wszystko i cześć i sławę u ludzi miała

Dzisiaj szczególnie istotne z perspektywy tradycji dydaktycznej wydaje się akcentowanie przez pedagoga praktycznego przygotowania uczniów do życia, czyli tzw. „życiowości”. Warto również uznać za słuszne jego metodologiczne zalecenie, aby nauczyciele czerpali przykłady z rodzimego otoczenia dziecka, tym samym w procesach zbliżania uczniów do regionu stosowali nauczanie oparte na zasadzie poglądowości oraz stopniowania trudności (zwanej zasadą przystępności), czyli: od tego, co bliskie, do tego, co dalsze ${ }^{2}$.

\section{Znaczenie więzi człowieka z miejscem wobec kryzysu wartości - per- spektywa współczesna}

Uwzględniając tradycje edukacyjne, współcześnie nie można pomijać znaczącej roli kultury w kształtowaniu tożsamości młodzieży oraz budowaniu poczucia bezpieczeństwa z najbliższym „uczłowieczonym” regionem. Dzisiejsza perspektywa badawcza zobowiązuje do przyjrzenia się wyznacznikom globalnej

${ }^{1}$ Rosner E., 1975, Rozważania wstępne, w: Regionalizm w nauczaniu języka polskiego $w$ szkole średniej, Rosner E. (red.), Warszawa, s. 15. Cyt. za: Piramowicz G., 1954, Powinności nauczycie..., w: Komisja Edukacji Narodowej. Wybór źródeł, Tync S., (zebrał i oprac.), Wrocław, s. 287. Zob. też. Regionalizm literacki w Polsce. Zarys historyczny i wybór źródeł, 2016, Chojnowski Z., Mikołajczak M. (red.), Mikołajczak M. (wstęp), Kraków.

2 Uniwersalizm poglądów pedagogicznych Grzegorza Piramowicza ujawnia się w propagowaniu przez niego „wychowania praktycznego”, przygotowującego uczniów do życia. Upominał się on o „szkolną życiowość” i zalecał, aby nauczyciele realizowali ćwiczenia przydatne w przyszłej pracy ucznia. Edmund Rosner przedstawiał rzecz następująco: „Wskazując potrzebę odniesień do rzeczywistości otaczającej uczniów, Piramowicz propagował nauczanie poglądowe, które wśród działaczy KEN miało wielu zwolenników, jak choćby Antoni Popławski, który na gruncie polskim zdefiniował istotną dla nachylenia procesu dydaktycznego do regionu zasadę: <od łatwiejszego do trudniejszego, od bliższego oczom i doświadczeniu do dalszego>" (Piramowicz 1954, 15-16). 
rzeczywistości społeczno-kulturowej, dostępnej na co dzień młodym ludziom. Prowokuje przy tym do namysłu nad współczesnymi uwarunkowaniami, które rozmaicie wpływają na relacje człowieka z miejscem (lub „nie-miejscem”) ${ }^{3}$ oraz innymi ludźmi, żyjącymi w określonej społeczności.

U podstaw myślenia na temat znaczenia więzi człowieka z miejscem na ziemi znajduje się przekonanie, że jest on szczęśliwy, gdy znajdzie swoje własne miejsce w świecie. Owo „ciepłe” miejsce, przytulne i wygodne jest jak „dach, pod którym chronimy się przed ulewnym deszczem, jak kominek, przy którym w mroźny dzień grzejemy dłonie” (Bauman 2008, 6). Paradoks polega na tym, że za przywilej bycia w bezpiecznym miejscu (np. we wspólnocie) trzeba nieraz płacić np. „autonomią”, „prawem do bycia sobą”. Według światowej sławy filozofa i socjologa możemy jednak uchronić się przed powtarzaniem starych błędów. W jego widzeniu świata dostrzec można ponadto kolejny paradoks: „będąc ludźmi, nie możemy obejść się bez wolności i poczucia bezpieczeństwa" (Bauman 2008, 11), co nie zwalnia nas z zaprzestania prób poszukiwania jednego i drugiego. Wypada jeszcze zauważyć, że próby rozwikłania problemu - czy można budować więzi człowieka z miejscem bez uwięzi? - wiążą się z odkrywaniem rozmaitych sprzeczności, których nie brakuje w czasach ponowoczesnych ${ }^{4}$. O ile samo pojęcie więzi definiowane jest w Nowym słowniku języka polskiego jako 'związek łączący jednostki', o tyle wyraz więzy ma dwojakie znaczenie; z jednej strony to rodzaj skrępowania, ograniczania np. rzemienie, sznury; z drugiej zaś to, co wiąże, jednoczy np. więzy rodzinne, przyjacielskie, małżeńskie ${ }^{5}$.

Niełatwo o jednoznaczne rozstrzygnięcia omawianego terminu w socjologii, gdzie dość płynnie traktuje się pojęcie więzi społecznych, choć zdaniem badaczy odgrywa ono: „pierwszoplanową rolę w opisach współczesnego społeczeństwa, nawiedzanego przez >kryzys więzi<, >redukcję więzi<, >rozpad więzi< należy do tych elementarnych pojęć socjologii, których treść uległa takiej banalizacji i u-zwyczajnieniu, że trudno jest ją w ogóle odtworzyć" (Marody, Poleszczuk 2004, 99). Nie wdając się w tym miejscu w szczegółowe definicje, warto zauważyć, że według znawców omawianej tematyki rozpad więzi społecznych oznacza rozpad społeczeństwa. Nie pozostaje zatem nic innego, jak przywołać jeszcze raz niezwykle ujmującą diagnozę Baumana, który sprytnie łączy wspólnotowość z indywidualnością jednostek, gdy stwierdza:

Wszyscy jesteśmy współzależni w naszym globalizującym się świecie (...), a jeśli w świecie jednostek ma zaistnieć wspólnota, może to być (i musi) jedynie wspólnota utkana ze wspólnej i wzajemnej troski... (Bauman 2008, 199-200).

\footnotetext{
${ }^{3}$ Por. Auge M., 2012, Nie-miejsca. Wprowadzenie do antropologii hipernowoczesności, Chymkowski R. (przeł.), Warszawa, s. 21. „Świat hipernowoczesności nie jest dokładnie tym, w którym wydaje się nam, że żyjemy, ponieważ żyjemy w świecie, którego jeszcze nie nauczyliśmy się oglądać. Powinniśmy nauczyć się od nowa myśleć o przestrzeni".

${ }^{4} \mathrm{Na}$ temat współczesnych paradoksów edukacyjnych interesująco pisze Kłakówna Z. A., 2003, Przymus i wolność. Projektowanie procesu kształcenia kulturowej kompetencji. Język polski $w$ klasach IV-VI szkoły podstawowej, gimnazjum i liceum, Kraków.

${ }^{5}$ Nowy słownik języka polskiego PWN, 2002, Sobol E. (red.), Warszawa, s. 1130.
} 
Potraktowanie więzi w edukacji humanistycznej jako uniwersum moralnego w pewien sposób łączy się z dydaktyczną koncepcją „człowieka pośrodku" sceny świata i prowadzi bezpośrednio do ustaleń współczesnych badaczy, podejmujących się szczegółowych rozważań na temat interesującego nas związku człowieka z miejscem ${ }^{6}$. Sygnalizując jedynie kłopoty terminologiczne, które napotykają przedstawiciele rożnych dziedzin nauki, np.: psychologii społecznej, geografii społecznej, humanistycznej, kulturowej, należy wymienić - za znawczynią Psychologii miejsca - przykłady niejasnych zakresów znaczeniowych pojęć: przywiązanie do miejsca, identyfikacja z miejscem, doświadczanie miejsca, zależność od miejsca, poczucie „bycia” w, osadzenie, zakorzenienie, przywłaszczenie, poczucie przynależności, topofilia, a także pokrewne im terminy opisujące stosunek do społeczności: przywiąanie do społeczności, doświadczanie wspólnotowości ${ }^{7}$ (Lewicka 2012, 105). Uwagę przykuwają również dość popularne w nauce rozróżnienia na afektywne przywiązanie do miejsca oraz poznawczą identyfikację z miejscem. Zakłada się przy tym, że pierwsze z nich opisuje przede wszystkim więź emocjonalną, drugie zaś zawiera wiedzę na temat cech kategorii, z którą człowiek się utożsamia. Niektórzy badacze uważają przywiązanie i identyfikację za dwie fazy tego samego procesu, zróżnicowanego w czasie, tzn. przywiązanie do miejsca wyprzedza włączenie tego miejsca do tożsamości. Rekonstrukcja badawcza relacji człowieka z miejscem nie jest łatwa. Bardziej odwołuje się do zdrowego rozsądku i potocznego rozumienia pojęć aniżeli do obszernej teorii. Omawiane kłopoty wynikają również z ogromu terminów stosowanych do opisu emocjonalnych związków człowieka z miejscem i nasuwają, zdaniem Marii Lewickiej, wiele wątpliwości:

Dla jednego badacza zatem twierdzenie „to miejsce jest częścią mnie” będzie wyrazem przywiązania do miejsca, dla drugiego natomiast - miarą utożsamienia się z miejscem (Lewicka 2012, 106-107).

Zgłoszone tutaj zastrzeżenia nie obniżają rangi miejsca ani jego znaczenia w doświadczeniu egzystencjalno-kulturowym człowieka. Proponowany kierunek myślenia odpowiada słownikowej definicji miejsca jako: „specyficznie ludzkiej przestrzeni doświadczenia świata, «przestrzeni znaczącej», obejmującej doświadczenia podmiotów w ich kulturowych, politycznych i społecznych aspektach" ${ }^{8}$. Wpisuje się on w potencjał geopoetyki ${ }^{9}$,

${ }^{6}$ Por. Geller E., Dąbrówka A., 2007, Słownik stylistyczny języka polskiego, Warszawa, s. 261-263. Tematyka miejsca skierowała moją uwagę w stronę wyrażeń i zwrotów językowych skrupulatnie odnotowanych (na trzech stronicach!) słownika. Wyraz hasłowy miejsce łączy się tutaj z pytaniami: KTO? CO? JAKIE? JAK? CO ROBIĆ? Zob. też Bańko M., 2006, Słownik dobrego stylu czyli wyrazy, które się lubia, Warszawa, s. 119-120.

7 Autorka podaje także pojęcia w języku angielskim.

${ }^{8}$ Męczkowska A., 2006, Locus educandi. Wokół problematyki miejsca $w$ refleksji pedagogicznej, w: Pedagogika miejsca, Mendel M. (red.), Wrocław, s. 39. Warto odnotować za Autorką, że we współczesnych dyskursach społeczno-kulturowych kategorię miejsca wykorzystuje się do opisu miejsc, które nimi nie są, w których przestrzeń doświadczenia świata przez człowieka, pozostaje w coraz słabszym związku z przestrzenią fizyczną.

9 We współczesnych orientacjach badawczych mocny akcent kładzie się na geopoetykę rozumianą jako „pojęcie-w-działaniu”. Według Elżbiety Rybickiej, pole działania geopoetyki nie odnosi się tylko do twórczości literackiej, ale też: „może ona współtworzyć (...) politykę tożsamości okre- 
jednocześnie koresponduje z refleksją pedagogiczną, kładącą szczególny nacisk na aktywną siłę miejsca, jego „siłę sprawczą”. Jak zauważa Astrid Męczkowska: „Miejsce jako przestrzeń doświadczania świata jest przestrzenią znaczącą dla procesów konstruowania tożsamości podmiotów" (Męczkowska 2006, 39).

Znacząca rola edukacji zorientowanej na świadome uczestnictwo w kulturze domaga się odpowiedzi na pytanie - jak w płynnonowoczesnej kulturze pomagać uczniowi w „zakorzenianiu” się? Jednym ze sposobów może być propozycja czytania tekstów literackich, które otwierają się na problemy młodych ludzi, odbywających wędrówki po znanych krakowskich miejscach, ale także (albo przede wszystkim) w głąb siebie.

Ponadczasowy postulat, by lektura prowadziła do umiłowania regionu i ludzi tam mieszkających, prowadzi bezpośrednio do lekcji polskiego oraz książek Doroty Terakowskiej, budzących niemałe zainteresowanie w gronie czytelników w wieku szkolnym (i nie tylko).

\section{Doświadczanie miejsc „tu” $\mathbf{i}$ „tam”}

Przyjmując założenie, że czytanie jest rodzajem zajmującej podróży w świat inny niż ten, który jest sztucznie wykreowany przez współczesne „pożeracze czasu” (media), z pewnością warto zaproponować uczniom realną wędrówkę po Krakowie. Jest ona możliwa dzięki lekturom wyraźnie z zacięciem geograficznym tj.: Babci Brygidy szalona podróż po Krakowie (Terakowska 2018) oraz Władca Lewawu (Terakowska 2016). O ile pierwszy tytuł nie zaskakiwał piątoklasistów pod względem miejsca akcji, o tyle rozszyfrowanie drugiego zajęło trochę czasu bardziej wybrednym (jeśli idzie o zainteresowania czytelnicze) siódmoklasistom, którzy nie od razu potrafili wskazać na ukryty w tytule Wawel. Warto też dodać, że uczniowie szkoły podstawowej nie zetknęli się jeszcze z fachowymi komentarzami na temat twórczości Doroty Terakowskiej, wielokrotnie nagradzanej, docenianej w świecie znawców literatury (Baluch 2014, 167), mieszkającej w Krakowie, co niewątpliwie najbardziej zwróciło uwagę młodych ludzi, ponieważ było bliskie ich życiowemu doświadczeniu. Wstępne wypowiedzi nieprofesjonalnych czytelników (uczniów) potwierdzały opinie profesjonalistów, którzy zauważali, że mamy do czynienia z książkami: „niby o znanych miejscach w Krakowie”, ale jednocześnie owianych tajemnicą, niezwykłością, co najmniej dziwnych. Znawcy literatury wskazywali też na kłopot związany z próbą typologii twórczości omawianej autorki, np.:

Trudno byłoby (...) określić jednoznacznie rodzaj pisarstwa Terakowskiej. Powieść obyczajowa dla dzieci i młodzieży? A może raczej moralitet? Fantasy? Baśń? Wydaje się, że rożne konwencje zbiegają się w jej tekstach, przeplatają, migają niczym światełka,

ślonych regionów czy miejsc”. Zob. Rybicka E., 2014, Geopoetyka. Przestrzeń i miejsce we współczesnych teoriach i praktykach literackich, Kraków s. 91-92. Autorka dostrzega we współczesnych teoriach miejsca i przestrzeni geograficznej ważne i inspirujące ujęcia, które akcentują aspekty kulturowe, doświadczeniowe, wyobrażeniowe oraz sprawcze. Zakreśloną tutaj współczesną perspektywę badawczą uważam za szczególnie ważną dla prowadzonych przeze mnie badań. 
których zadaniem - podobnie jak ulicznych drogowskazów sygnalizacyjnych - jest wskazywanie możliwości: stop, trzeba pomyśleć, teraz oczekiwanie, czyli faza analizy i interpretacji, aż wreszcie - cała naprzód, droga wolna (czy może lepiej rozpoznana) ${ }^{10}$.

Omawiany problem zmniejszy się nieco, jeśli przyjmiemy, że nie idzie tutaj o teksty mądrościowe, ilustrujące nadrzędne prawdy, ale o zachęcanie potencjalnych czytelników,

by otworzyć się na przygodę, wyruszyć w podróż w nieznane (...), by choć przez moment poczuć dotyk Nienazwanego. Bowiem epifanie, przebłyski znaczenia są tu najwyższymi wartościami (Bojda 2004, 15).

W związku z powyższym nie pozostawało nic innego, jak zaproponować uczniom znaną w dydaktyce drogę uczenia (się) - od zdziwienia do lektury, ${ }^{11}$ połączoną z doświadczaniem miejsc najbliższych i zarazem (nie)zwykłych.

Przyjęta perspektywa dydaktyczna wynikała z myślenia o przestrzenności jako doświadczeniu poczucia zamieszkiwania, charakterystycznego dla nowoczesnej fenomenologii z relacyjnym byciem w przestrzeni. Potrzebę emocjonalno-intelektualnego „wrastania” człowieka w przestrzeń uzasadnić można na sposób, który przyjęła znawczyni hermeneutyki miejsca Hanna Buczyńska-Garewicz. Objaśnia ona:

Człowiek w swym bycie konstytuuje związek z otoczeniem, dzięki któremu on zostaje mieszkańcem, miejsca i okolice stają się domem. Okolica bliska i przyswojona, domowa nabiera swych cech swojskości jedynie dzięki temu, że zostaje wypełniona określonymi jakościami, że staje się jednoznacznym zbiorem treści ukonstytuowanych i dostępnych w rozumieniu. Związek zamieszkiwania jest więc z istoty swej reakcją duchową, stosunkiem rozumienia (Buczyńska-Garewicz 2006, 10-11).

Według znawców metodyka współczesnego regionalizmu powinna właśnie opierać się „na uczeniu rozumiejącego czytania przestrzeni kulturowych jako miejsca”12, stąd też w trakcie działań lekcyjnych dokonano próby rozpoznania dwóch odmiennych (a przez to nienudnych) światów: 1) miejsc realnych, bliskich doświadczeniu życiowemu ucznia; 2) miejsc równoległych, utrwalonych w lekturze.

${ }_{10}$ Bojda W., 2004, Kłopot z Terakowska, „Guliwer”, nr 2, s. 15. Otwieranie się na przygodę było odpowiednie dla wieku i możliwości percepcyjnych uczniów szkoły podstawowej, ale nie wykluczało w klasach starszych zwrócenia uwagi na chwyt fantazmatu (głębokiego pragnienia bohatera), który objawia się w literaturze m.in. poprzez sobowtóry, lustrzane odbicia, fantastyczne migotanie światów realnych i nierealnych. Ów „człowiek we wewnętrzny”, bohater książek Terakowskiej, dąży do głębi i prawdy swojej osobowości bez maski. (Por. Baluch 2014, 167-172). Zob. też. Klejnocki J., 2013, Czytanie powinno być przygoda, „Polonistyka”, nr 6, s. 8-9.

11 Nie mogę w tym miejscu pominąć znakomitej lektury księdza Jana Twardowskiego, pt. Nie tylko wrona chodzi zdziwiona,2015, Iwanowska A. (wybór i oprac.), wyd. II, Poznań, której już sam tytuł nawiązuje do zdobywania doświadczenia poszukującego.

12 Budrewicz Z., 2009, Wyjdźmy z muzeum na uliczkę. Zobowiązania kulturowe edukacji regionalnej, w: I Dydaktyczny wiatr od morza. Różnorodne aspekty kształcenia kompetencji kulturowej w edukacji polonistycznej, Różańska G. (red.), Ustka, s. 288-290. W proponowanych dalej działaniach dydaktycznych chodzi o cel zgrabnie sformułowany przez Zofię Budrewicz: „Za pośrednictwem odpowiednio dobranych treści można wywołać swoiste, pożądane wychowawczo reakcje na sytuacje symbiozy człowieka z miejscem jego pochodzenia, na wzory (auto)identyfikacji z polską ziemią i jej kulturą". Warto wspomnieć, że zdaniem badaczy regionalizmu, przestrzeń i miejsce są kategoriami pojęciowymi „szczególnie pedagogicznie zaniedbanymi”, co w pewien sposób uzasadnia potrzebę projektów lekcyjnych, skupionych wobec lektury i miejsca. Zob. też Petrykowski P., 2003, Edukacja regionalna. Problemy podstawowe i otwarte, Toruń, s. 211. 
Założenie, że wycieczka literacka po Krakowie znakomicie wpisuje się w kształcenie literackie ze współczesnym regionalizmem, zobowiązywało do poznania zabytków, miejsc i dziejów kultury w najbliższym szkole środowisku. Kierowano się przy tym inspiracjami dydaktycznymi, u podstaw których znajduje się utrwalanie treści lekcyjnych poprzez wiązanie emocjonalne z „miejscami, w których uczeń żyje lub które odwiedzał, z [jego] osobistymi przeżyciami i doświadczeniami percepcyjnymi"13. Urok miejsca (krakowski genius loci) i lektury Terakowskiej miały tutaj niemałe znaczenie.

Etapy pracy ${ }^{\mathbf{1 4}}$ nad utworami zostały uprzednio dobrze przemyślane. Jeszcze przed przeczytaniem lektur uczniowie zostali poproszeni o zwrócenie uwagi zwłaszcza na te fragmenty, które dotyczą znanych im miejsc krakowskich. Rozpoznanie wstępne uczniowskiego odbioru wyraźnie wskazywało na zainteresowanie młodzieży odbywaniem interesujących wędrówek bohaterów pomiędzy światami równoległymi: „tu” i „tam” - blisko i daleko. Niewątpliwie potwierdzało się przekonanie Anity Wolanin, że owa fantastyczna podróż w czasie i przestrzeni odbywa się dość nieskomplikowanie:

Inne światy otwierają się na bohaterów, oni zaś poddają się oddziaływaniu tajemniczej, absorbującej siły. Powołani do wypełnienia określonej misji, realizują ją z korzyścią dla obcego świata. Przekraczanie granic alternatywnych rzeczywistości odbywa się płynnie i gładko (Wolanin 2015, 115).

Interesujące dla uczniów okazały się mechanizmy przekraczania granic pomiędzy alternatywnymi światami. Zwrócili oni uwagę na magiczne przedmioty i miejsca albo niezwykłe umiejętności (stan umysłu) bohaterów. Do pierwszej grupy zaliczano chustkę i parasol babci Brygidy oraz interesującą grę zwaną „oczami wyobraźni”, która dawała możliwość pojawiania się $\mathrm{w}$ różnym wybranym miejscu i czasie np.: XIII-wiecznym Krakowie zaatakowanym przez Tatarów (Bartek wraz z opiekunką); Bartek z Władcy Lewawu przemieszcza się z Krakowa do Wokarku mrocznym, nieprzyjemnym tunelem, by tą drogą wrócić stamtąd - tu (do Krakowa). Wnioski starszych uczniów prowadziły do uchwycenia zmian w zachowaniu i myśleniu Bartka, który wprawdzie powracał tą samą drogą, ale już nie ten sam; był silniejszy, bardziej odważny. Tytułowy bohater wyraźnie imponował nastoletnim czytelnikom swoim silnym charakterem.

Wycieczka po Krakowie śladami miejsc literackich polegała przede wszystkim na przyglądaniu się wskazanym punktom. Kierunek trasy wyznaczały lektury. Prowadzące lekcje sterowały uwagą uczniów, na początku

${ }^{13}$ Zob. rozważania na temat wycieczki polonistycznej Uryga Z., 1996, Godziny polskiego. Z zagadnień kształcenia literackiego, Warszawa - Kraków, s. 192-193.

14 Etapy zajęć w terenie realizowano w ramach ćwiczeń praktycznych z Dydaktyki języka polskiego $w$ szkole podstawowej pod moim kierunkiem. W latach 2016/2017 oraz 2017/2018 sprawowałam nadzór merytoryczny i metodyczny nad przygotowaniem konspektów i przeprowadzeniem lekcji terenowych przez studentów filologii polskiej UP im. KEN w Krakowie. Zajęcia pomyślane były jako składowa część interesującej (uczniów i studentów) innowacji pedagogicznej „Śladami krakowskich miejsc literackich z naszych lektur", realizowanej w Szkole Podstawowej nr 7 w Krakowie przez współpracującą od wielu lat z Uniwersytetem Pedagogicznym mgr Irenę Rejduch. Polonistce, wszystkim studentkom (szczególnie prowadzącym niełatwe lekcje w terenie), a przede wszystkim uczniom składam serdeczne podziękowanie za dobrą współpracę międzypokoleniową i lekcję życia, polegającą na uczeniu się od siebie nawzajem. 
mocno rozproszoną. Głośne odczytanie odpowiedniego fragmentu lektury prowadziło do zatrzymania się na chwilę, aby „objąć” miejsca zdarzeń zmysłami (wzrokiem, słuchem, węchem, dotykiem) i tym samym na dłużej zapamiętać treść książki. Można było odnieść wrażenie, że uczniowie "chwytają miejsce i czas”; dziwują się wskazanym obiektom, jakby dostrzegali je po raz pierwszy, chociaż niektórzy z nich mieszkają w Krakowie od kilkunastu lat ${ }^{15}$.

Trzeba zaznaczyć, że młodzież szkolna odbywała wędrówkę do różnych miejsc (nie)zwykłych, podobnie jak postaci Terakowskiej. Trudno do końca stwierdzić, w jakim stopniu to realne doświadczanie miejsc przyniosło uczniom korzyści duchowe. Aktywność fizyczna uczniów miała jednak swoje znaczenie, ponieważ łączyła się z przekonaniem, że „przemieszczanie się, ruch oznacza zmianę w życiu bohaterów, a ta jest szczególnie pożądana" (Wolanin 2015, 93).

Uczniowie krakowskich klas piątych podążali śladami Bartka i jego przybranej babci. Rozumieli świat fikcyjny, w którym oniryczne wędrówki chorego na grypę chłopca obejmują najciekawsze miejsca i zarazem stanowią interesujący przewodnik po zabytkach rodzinnego (dla uczniów także) Krakowa. Z łatwością wyobrażali sobie babcię Brygidę, znającą dzieje miasta, ładnie pachnącą (czekoladą, bananami, lodami, smażonym kurczakiem...), potrafiącą zajmująco opowiadać o swoich rozlicznych podróżach, które uwielbiała. Prowadzące wycieczkę, wcielające się w rolę babci, zadbały również o odpowiedni strój (kolejny wyróżnik starszej pani) i czerwoną parasolkę. Elementy przebrania przykuwały uwagę uczniów, którzy chętnie opuścili mury szkoły, by następnie wbić się w tłum podążający ulicą Floriańską z hotelem „Pod Różą”, gdzie stacjonowała bohaterka, („dwa kroki” od domu Bartka). Dotarli do Rynku Głównego, tam przyglądali się wieży Mariackiej: „jednej z dwóch wież największego krakowskiego kościoła Najświętszej Marii Panny, tego, w którym jest słynny ołtarz Wita Stwosza - rzadko jest otwarta dla turystów" (Terakowska 2018, 15), po której książkowych bohaterów oprowadzały krasnoludki. Następnie udali się znanymi ulicami: Grodzką i Kanoniczą, by dotrzeć do Smoczej Jamy i odwiedzić smoka - jarosza, jak wiadomo „syna tego, którego zatruli baraniną, za króla Kraka" (Terakowska 2018, 42). W sąsiedztwie smoka, co miało tutaj osobliwe znaczenie, odbyła się lekcja ekologii, nakazująca posprzątanie śmieci po cukierkach oraz wrzucenie ich do kosza, zgodnie z pouczeniem babci Brygidy.

15 Postawy młodzieży korespondują z diagnozami socjologów i dydaktyków. Od lat zwraca się uwagę na potrzebę wyzwalania aktywności poznawczej wśród uczniów na lekcjach polskiego, by służyła ona kształtowaniu kompetencji kulturowych i postaw tożsamości regionalnej. Przywołuje się wyraźne skutki globalizacji w sferze wiedzy i postaw młodzieży polskiej, która nieźle orientuje się w rzeczach, z którymi na co dzień nie styka się, ale za to przedmioty z najbliższego otoczenia są im nieznane. W konsekwencji to, co bliskie - pozostaje nieznane. Zob. Bukraba-Rylska I., 2001, Czy regionalizm jest dla młodziė̇y? w: Edukacja regionalna młodzieży w rodzinie, szkole i środowisku, Lergetporer-Jakimow A. (red.), Wrocław, s. 75-82. Por. Budrewicz Z., 2006, Tradycje i współczesność regionalizmu edukacji polonistycznej, w: Region i edukacja. Literatura - kultura - społeczeństwo, Budrewicz Z., Kania M. (red.), Kraków, s. 17-18. 
Warto dodać, że lekcję $\mathrm{w}$ terenie łączono z proponowaną w lekturze zabawą, która pozwalała zobaczyć „oczami wyobraźni” wybrane miejsce przed wiekami. Przeniesienie w czasie ułatwiały przygotowane wcześniej podania i legendy o Krakowie, które (jak się okazało) uczniowie dość dobrze znali z wcześniejszych etapów edukacji, stąd jedynie utrwalano ich treść (np. Legenda o księciu Kraku i Smoku Wawelskim, Legenda o krakowskim Bazyliszku Legenda o Królewnie Wandzie, Legenda o przerwanym hejnale... ${ }^{16}$. Piesza wędrówka spod szkoły w okolice Wawelu (i z powrotem) sprzyjała bezpośredniemu zetknięciu się uczniów z miejscami bliskimi, ale odkrywanymi przez nich niejako na nowo dzięki lekturze i zaangażowaniu zmysłów. Zapewne wycieczka przyczyniła się do bardziej refleksyjnego myślenia o miejscu, w którym przyszło im żyć i uczyć się, o czym świadczyłyby indywidualne wypowiedzi uczniów, sygnalizujących potrzebę powrotu do oglądanych miejsc w towarzystwie osób najbliższych („Ja tu jeszcze wrócę”!).

Piesze wędrówki po Krakowie (bliskim i dalekim) dla uczniów klas siódmych miały jeszcze inne znaczenie. Podążając za głównym bohaterem Władcy Lewaku, bardziej zwracali uwagę na zmiany w jego charakterze powstałe podczas przemieszczania się pomiędzy dwoma równoległymi światami. Nie bez znaczenia dla młodocianych czytelników był fakt, że Bartek w chwili wyruszenia w podróż miał trzynaście lat, a zatem obserwowali swojego rówieśnika w momencie przełomowym, wyznaczającym przejście z dzieciństwa w okres młodzieńczy, zaś jego wyprawa został nazwana Trzynastą Podróżą w Poszukiwaniu Mamy (Wolanin 2015, 93). Podczas swoich (nie)zwykłych wędrówek dotarł on do Smoczej Jamy, a następnie skalnym korytarzem przedostał się do Wokarku. W nowej alternatywnej rzeczywistości zastał lustrzany świat, w tym nazwy miejsc np. Ałsiw - Wisła, Wokark - Kraków, U Ałaks - ul. Skałeczna, Lewaw - Wawel. Co ciekawe, obca rzeczywistość przypominała znany mu dotychczas świat i miejsca, jak stwierdzał: „niby takie same, zarazem jakieś inne” (Terakowska 2016, 20).

Bartek imponuje uczniom najbardziej, gdy pokonuje budzące odrazę Pajęczaki, by w końcu o północy uwolnić Allian spod tyranii Nienazwanego. Chcą podążać jego śladami. Podróż do (nie)zwykłej rzeczywistości uczniowie prowadzą według wskazań lektury, stąd wędrówka po Krakowie wygląda następująco: ulica Skałeczna, Smocza Jama, Wawel z komnatami zamkowymi i Salą Tronową. Rolę pośrednika przenoszącego młodzież do odmiennej rzeczywistości pełni lektura. Doświadczając miejsc, dla niektórych bliskich od urodzenia, z łatwością odtwarzają przebieg poszczególnych zdarzeń, utrwalonych w literaturze. Po odczytaniu odpowiednich fragmentów, prowadzące lekcje studentki nawiązują także do znanych uczniom legend krakowskich. Można pokusić się o stwierdzenie, że wędrówka dla starszych

${ }^{16}$ Podczas zajęć w terenie korzystano z następujących fragmentów opracowań: Adamczewski J., 2013, Legendy starego Krakowa, Kraków; Wollny M., 2007, Tropem Smoka. Krakowskie legendy, tradycje i ciekawostki. Bajeczny przewodnik po magicznym Krakowie dla dzieci i młodzieży, Wollny Z. (il.), Kraków. 
klas szkoły podstawowej przypominała poszukiwanie Nieznanego, ale i swojego miejsca w świecie, swojej tożsamości.

\section{Próba podsumowania}

W procesie kształtowania poczucia zakorzenienia przydatny jest aspekt ujmujący przywiązanie do miejsca jako funkcja czasu (por. Petrykowski 2003, 241), stąd zasadne wydaje się stwierdzenie, że oto nadszedł czas i miejsce na konkluzje. Jak rozbudzać wśród młodych ludzi zainteresowanie tym, co najbliżej - przestrzenią, konkretnym miejscem, najbliższym regionem?

Propozycja lekcji literackiej w macierzystym środowisku ucznia przypomina o sprawdzonych w międzywojniu propozycjach i wartościach „puszczania korzeni w duszę”. Wątpliwości nastolatków: „Kim jestem? Skąd jestem?” starano się rozwiać w kontakcie z lekturą i konkretnym topograficznie terytorium kulturowym, które (jak zakładano) oddziałując wychowawczo na młodego człowieka, prowadziły do przekonania, że oto „Jestem Stąd, dlatego jestem Kimś" ${ }^{17}$. Wycieczka literacka udowodniła jeszcze, że o swojskości i bliskości najbliższej okolicy decyduje jej poznanie i rozumienie, inaczej pozostaje ona dla młodego człowieka obca i daleka. Z obserwacji młodzieży krakowskiej dość jasno wynika wychowujące działanie lektury i miejsca - działanie miejscem" (Mendel 2006, 29), ponieważ młodzi ludzie chcą czytać (dopytują o inne książki Terakowskiej) i wracać do miejsc realnych opisanych w lekturach. W ich przeżyciu duchowym mieściły się doświadczenia indywidualne i kulturowe, za które przecież będą odpowiedzialni w przyszłości nie tylko wobec siebie, lecz również przyszłych pokoleń i najbliższej przestrzeni. Niewątpliwie potwierdziło się znane w nowoczesnej dydaktyce polonistycznej przekonanie, że w podróży po dziedzictwie kulturowym regionu nie wystarczy skoncentrować się na przekazie informacji, wiedzy. Przede wszystkim, zgodnie z zaleceniami Piotra Petrykowskiego, należy skoncentrować się na różnorodności i bogactwie działań pedagogicznych:

Poczucie związku z innymi, z miejscami, przedmiotami i ich desygnatami kształtuje się nie tyle dzięki ilości posiadanych na ich temat informacji, ale dzięki doświadczaniu - człowieka, miejsca, przedmiotu. Co więcej - doświadczanie oznacza także odwołanie się do wszystkich zmysłów, jakimi obdarzony jest człowiek (Petrykowski 2003, 212).

Pozostaje jeszcze uświadomienie sobie pewnej ważnej zależności: genius loci współtworzy przestrzeń duchową człowieka, kształtując w rezultacie przestrzeń miejsca, stąd też warto troszczyć się o budowanie wzajemnych związków człowieka z miejscem. Starano się pokazać, że jest to możliwe dzięki czytaniu, które stwarza możliwości rozmowy o wartościach, często zatracanych we współczesnym świecie. Mówiąc językiem Baumana,

${ }_{17}$ Można tutaj pokusić się o analogię do innej, lubianej przez uczniów lektury, która znakomicie buduje przekonanie, że lepiej być Anią z Zielonego Wzgórza niż znikąd. Zob. L. M. Montgomery, Ania z Zielonego Wzgórza. 
chodziło o sytuację budowania „wspólnoty” czytelniczej, „utkanej ze wspólnej i wzajemnej troski” (Bauman 2008, 199-200). Wymagała ona od nauczyciela i uczestników wycieczki wrażliwości aksjologicznej, która przejawiała się m. in. w umiejętności słuchania drugiego człowieka (por. Janus-Sitarz 2009, 214-215), zderzenia z nieoczywistościami, próby zrozumienia, że wędrówki polonistyczne śladami bohaterów lektur nie są zwykłym przemieszczaniem się po (nie)zwyczajnym Krakowie, najbliższym środowisku. Otwieranie się na literackie przygody Bartka oznaczało odbycie wraz z nim wyimaginowanych wędrówek z wymarzoną bliską osobą (babcią), dobrze znającą dzieje królewskiego niegdyś grodu. Towarzyszyła im radość odkrywania najciekawszych, zabytkowych miejsc, nie zawsze dostępnych przypadkowym turystom. Wspólne wyprawy z osieroconym bohaterem z Władcy Lewawu do lustrzanego świata, znajdującego się po drugiej stronie miasta i odwiedzanie niby znanych miejsc, uświadomiły młodym ludziom znaczenie wartości w życiu człowieka np. miłości i rodziny, potrzebę jej odzyskania i posiadania ${ }^{18}$. Znacząca była tutaj tajemnica, również $\mathrm{w}$ odniesieniu do sposobów odczytania obydwu powieści. Nie ma wątpliwości, że rola uczniów, spontanicznych odbiorców lektur Terakowskiej, sprowadzała się do rozszyfrowania sensu tajemniczych podróży bohaterów literackich do różnych miejsc. Mierzenie się bohaterów książkowych z Nieznanym tj. własnymi lękami, niebezpiecznymi sytuacjami i wyzwaniami losu prowadziło jeszcze do odkrycia, że wędrówka może być rozumiana jako poszukiwanie własnego miejsca w świecie i próba zrozumienia siebie, własnej tożsamości (por. Wolanin 2015, 92-93).

Wypada jeszcze na koniec zastanowić się nad rozmaitymi „szkołami czytania". Jak budować na lekcjach języka polskiego więzi nastolatków z lekturami? Na myśl przychodzi obraz „ciepłego” miejsca jako wspólnoty doświadczeń ludzi czytających; doświadczających miejsc opisanych w lekturze. Wyprowadzając wnioski dydaktyczne ze wspólnoty utkanej z jednostkowych, odmiennych potrzeb czytelników, wrażliwości i możliwości młodych ludzi, trzeba przyznać rację Annie Janus-Sitarz:

Szkoła powinna być miejscem, w którym pomaga się młodemu czytelnikowi odnaleźć własną drogę do czerpania przyjemności ze spotkań z literaturą poprzez poznawanie (testowanie, „smakowanie”) wraz z nim różnorodnych praktyk czytania... (Janus-Sitarz 2009, 367).

Wypowiedź znawczyni współczesnej dydaktyki polonistycznej doskonale dopełnia myśl otwierająca się na uniwersalny charakter miejsc/a, gdyż „O tym, kim człowiek jest, coraz wyraziściej mówią miejsca, z których nie tylko chciał, ale i mógł siebie zbudować" (Mendel 2006, 31).

18 Zob. Tyl M., 2016, System wartości we „Władcy Lewawu” Doroty Terakowskiej. Propozycje pracy $z$ lektura $w$ szkole podstawowej, „Polonistyka”, nr 6, s. 50-53. Zob. też. K. M. Pławecka, O rozbudzaniu miłości do lektury (i miejsca) z perspektywy nowoczesnej praktyki polonistycznej. Referat wygłosiłam w Rzeszowie podczas konferencji na temat Życie bez miłości jest (nie)możliwe w 2018 roku [publikacja w druku]. W niniejszym artykule znalazły się fragmenty, które zostały uzupełnione i gruntownie przeredagowane. 


\section{Bibliografia:}

Terakowska Dorota, 2018, Babci Brygidy szalona podróż po Krakowie, Butenko B. (oprac. graficzne), Kraków.

Terakowska Dorota, 2016, Władca Lewawu, Kraków.

Auge Marc, 2012, Nie-miejsca. Wprowadzenie do antropologii hipernowoczesności, Chymkowski R. (przeł.), Warszawa.

Baluch Alicja, 2011, Być razem poprzez wspólne czytanie, „Guliwer”, nr 1.

Baluch Alicja, 2014, Tajemniczy świat Doroty Terakowskiej, „Annales Universitatis Paedagogicae Cracoviensis. Studia Historicolitteraria”, t. 14.

Bauman Zygmunt, 2008, Wspólnota. W poszukiwaniu bezpieczeństwa w niepewnym świecie, Margański J. (przeł.), Kraków.

Bojda Wioletta, 2004, Kłopot z Terakowska, „Guliwer”, nr 2.

Buczyńska-Garewicz Hanna, 2006, Miejsca, strony, okolice. Przyczynek do fenomenologii przestrzeni, Kraków.

Budrewicz Zofia, 2006, Tradycje i współczesność regionalizmu edukacji polonistycznej, w: Region i edukacja. Literatura - kultura - społeczeństwo, Budrewicz Z., Kania M. (red.), Kraków.

Budrewicz Zofia, 2009, Wyjdźmy z muzeum na uliczkę. Zobowiązania kulturowe edukacji regionalnej, w: I Dydaktyczny wiatr od morza. Różnorodne aspekty kształcenia kompetencji kulturowej w edukacji polonistycznej, Różańska G. (red.), Ustka.

Bukraba-Rylska Izabella, 2001, Czy regionalizm jest dla młodzieży? w: Edukacja regionalna młodziézy $w$ rodzinie, szkole i środowisku, Lergetporer-Jakimow A. (red.), Wrocław.

Janus-Sitarz Anna, 2009, Przyjemność i odpowiedzialność w lekturze. O praktykach czytania literatury w szkole. Konstatacje. Oceny. Propozycje, Kraków.

Lewicka Maria, 2012, Psychologia miejsca, Warszawa.

Mendel Maria, 2006, Pedagogika miejsca i animacja na miejsca wrażliwa, w: Pedagogika miejsca, Mendel M. (red.), Wrocław.

Marody Mirosława, Giza-Poleszczuk Anna, 2004, Przemiany więzi społecznych. Zarys teorii zmiany społecznej, Warszawa.

Myrdzik Barbara, 2007, W poszukiwaniu przestrzeni. Refleksje na temat sensu czytania nie tylko „lektur szkolnych”, w: Czytanie tekstów kultury. Metodologia. Badania. Metodyka, Myrdzik B., Morawska I. (red.), Lublin.

Petrykowski Piotr, 2003, Edukacja regionalna. Problemy podstawowe i otwarte, Torun.

Regionalizm literacki w Polsce. Zarys historyczny i wybór źródeł, 2016, Chojnowski Z., Mikołajczak M. (red.), Mikołajczak M. (wstęp), Kraków.

Rybicka Elżbieta, 2014, Geopoetyka. Przestrzeń i miejsce we współczesnych teoriach i praktykach literackich, Kraków.

Tyl Marzena, 2016, System wartości we „Władcy Lewawu” Doroty Terakowskiej. Propozycje pracy z lektura w szkole podstawowej, „Polonistyka”, nr 6. 
Uryga Zenon, 1996, Godziny polskiego. Z zagadnień kształcenia literackiego, Warszawa - Kraków.

Wolanin Anita, 2015, Twórczość Doroty Terakowskiej. Spotkanie z Nieznanym, Warszawa.

Yi-Fu Tuan, 1987, Przestrzeń i miejsce, Morawińska A. (przeł.), Warszawa.

\section{O Autorce:}

Katarzyna Maria Pławecka, dr, łączy zainteresowania polonistyczne z bibliotekoznawczymi. W trakcie sześciu lat studiów (WSP im. KEN Kraków) ukończyła dwa kierunki: Bibliotekoznawstwo i Informację Naukowo-Techniczną oraz Filologię Polską. Zatrudniona na stanowisku adiunkta w Katedrze Dydaktyki Literatury i Języka Polskiego Instytutu Filologii Polskiej Uniwersytetu Pedagogicznego; członkini Pracowni Edukacji Regionalnej. Autorka monografii Przygotowanie polonistyczne uczniów wiejskich gimnazjów $w$ perspektywie dalszego kształcenia (na przykładzie gminy Laskowa) oraz publikacji poświęconych szczególnie realizacji treści regionalnych w świecie globalnym, edukacji kulturowo-medialnej (tradycja i współczesność), różnym aspektom samokształcenia. Zainteresowania badawcze łączy z wychowaniem dzieci, a także obserwacją i analizą edukacyjno-kulturowych uwarunkowań macierzystego środowiska. Związana z Krakowem, zafascynowana Limanowszczyzną.

e-mail: katarzyna.plawecka@up.krakow.pl 
